Article

\title{
The Drivers of China's Regional Carbon Emission Change-A Structural Decomposition Analysis from 1997 to 2007
}

\author{
Ling Yang ${ }^{1, *(\mathbb{D})}$ and Michael L. Lahr ${ }^{2}$ (D) \\ 1 School of Economics and Finance, Xi'an Jiaotong University, Xi'an 710049, Shaanxi, China \\ 2 Edward J. Bloustein School of Planning and Public Policy, Rutgers The State University of New Jersey, \\ New Jersey, NJ 08901, USA; lahr@rutgers.edu \\ * Correspondence: lynnone@gmail.com
}

Received: 8 April 2019; Accepted: 4 June 2019; Published: 12 June 2019

\begin{abstract}
Using three official multiregional input-output tables and carbon emission data, we decompose the change in carbon emission for eight regions of China between 1997 and 2007. We do so according to the following seven partial effects: (i) Changes in energy end-use structure, (ii) effect of energy intensity, (iii) the added value's share of gross output, (iv) changes in sub-industry structure, (v) changes in the substitution of import for intermediate inputs, and changes in (vi) structure and (vii) level of final demand. We find energy intensity contributes most to $\mathrm{CO}_{2}$ abatement throughout China, while other factors vary widely across the different regions. We suggest that governments consider regional disparity and $\mathrm{CO}_{2}$ flows when formulating policies; structural change with an eye toward energy-savings and general efficiency improvements, like better insulated buildings, are among measures we deem effective.
\end{abstract}

Keywords: China; structural decomposition analysis; regional carbon emissions; energy resources

\section{Introduction}

As the largest carbon emitter, China has made substantial efforts to reduce carbon emission. At the 2009 United Nations Climate Change Conference in Copenhagen, China's government announced that by 2020 China will reduce its carbon intensity by 40-45\% from its 2005 level. In 2015, China promised in its Enhanced Actions on Climate Change: China's Intended Nationally Determined Contributions that it would achieve its peak carbon dioxide emission around 2030 and make best efforts to peak earlier, along with lowering carbon dioxide emission per unit of GDP by 60-65\% from the 2005 level. Meanwhile, a large number of studies have been published to uncover the driving force of China's carbon emission.

In fact, many papers have studied the sources of carbon emission change in China [1-3]. All of them have come to a similar conclusion-final uses, including exports, capital investment, and consumption, largely have caused China to increase its emissions of $\mathrm{CO}_{2}$. That is, China's efforts at improving energy efficiency are being outpaced by emission increases due to rises in the final uses of commodities the nation produces. Nonetheless, each set of researchers has had a particular focus. Guan et al. (2009) investigated China's emissions from 2002 to 2005 [3]; Guan et al. (2008) forecast carbon emissions through to 2030 and Liu et al. (2007) focused strictly on carbon emissions by China's intermediate users (commodity production that is not delivered to final uses) [1,2]. But few have studied emissions changes below the national level. The local characteristics and constraints of each region are seldom considered, despite the considerable heterogeneity across China's regions. Therefore, a regional analysis is necessary since carbon emissions derive from different sources in different regions, as pointed out by Huang and He (2011) [4]. 
To better understand the drivers of aggregate carbon change, the precondition of providing feasible climate policies is presented. In the literature, two methods are often used: Index decomposition analysis (IDA) and structural decomposition analysis (SDA) [5-8]. Below, we review several papers that focus on China's regional carbon emission change. They use either IDA or SDA methods; the first three studies use IDA and the others use SDA. Compared to IDA, SDA can touch on issues from both a supply- and demand-side perspective using rich datasets; it even accounts for the interdependence of industries.

Feng et al. (2009) investigated the carbon emission change of five regions in China with an IPAT (Influence, Population, Affluence, Technology) model for the 1949-2002 period [9]. The decomposition of the change in carbon emissions they used was clear from the acronym IPAT, as it examines the influences of population, affluence (consumption expenditures per capita), and technology (emission intensity). They identified major differences in the proximate causes of emission changes between southeast and northwest China and between its urban and rural areas. In particular, technology change did not compensate for emission rises due to population growth and the rising wealth of the typical Chinese citizen. Zhang et al. (2013) decomposed China's carbon emissions by province using a logarithmic mean divisa index (LMDI) of changes in four factors: Consumption expenditure per capita, energy consumption's share of total household consumption, population structure, and total population [10]. The first two factors were main drivers of the growth in carbon emissions in their analysis, yet regional differences were distinct across all four factors. Liu et al. (2010) performed a similar provincial decomposition and attributed most of China's $\mathrm{CO}_{2}$ emissions to such major industrial provinces as Hebei, Jiangsu, Zhejiang, Shandong, Henan, and Guangdong [11].

Several papers adopt SDA by using China's multiregional input-output (MRIO) tables, but they either focus on forecasting China's regional carbon emissions (Liang et al., 2007) or on carbon accounting [12]. For example, using a 30-province MRIO table for 2007, Feng et al. (2013) pointed out that the lion's share of carbon emissions in western provinces derives from consumption in eastern provinces. Indeed, the share reaches as high as $80 \%$ [13]. Meng et al. (2013) explain the relationship between China's interregional spillover of $\mathrm{CO}_{2}$ emission and domestic supply chains for 2002 and 2007 [14]. They show that a region's $\mathrm{CO}_{2}$ emissions depends on its intra-regional production technology (i.e., the magnitude of regional direct requirements), energy intensity (energy use per unit of gross output), as well as its position and degree of participation in domestic and global supply chains. To the best of our knowledge, only Feng et al. (2012) examine China's regional carbon emission change using SDA [15]. Using just three regions-eastern, central, and western China-they show how changes in population, technology, economic structure, urbanization, and household consumption patterns drive regional $\mathrm{CO}_{2}$ emissions from 2002 to 2007. They find a significant gap between the three economic zones in terms of $\mathrm{CO}_{2}$ emission and also find that the "greening" of the more developed areas is not only due to superior technology but also because of externalizing production and pollution to the poorer regions in China.

We also use SDA, as it allows us to analyze $\mathrm{CO}_{2}$ emission from both the supply and demand sides. Further, we contribute to the existing literature by, first of all, incorporating the mix of energy resources and the energy intensity of each into our analysis, something that has rarely (if ever) been examined within an SDA framework. Burning fossil fuels accounts for over $90 \%$ of all carbon emissions in China [16]. This is not so exceptional, as such a share also holds in the US. Still, per unit of energy produced, there is great variance in the carbon emissions across the different fossil fuels. For example, the conversion factor for LPG (Liquefied Petroleum Gas) is three times more efficient than coke oven gas. Nonetheless, some modest alterations to the structure of energy transformation could reduce China's carbon emission substantially. Coal comprised about $70 \%$ of fossil fuel consumption in the 1980s and 1990 s and only decreased to $60.4 \%$ by 2017 . Within the country, the west consumes more coal because of ready access to the resource; indeed, as a result the west's industry structure is highly oriented toward energy-intensive industries. So, it should be clear that energy intensity and energy structure are inextricably intertwined with the analysis of carbon emissions. Most SDA studies successfully 
incorporate many aspects of supply and demand sides of an economy, but energy intensity and the mix of energy resources typically only are implicitly included in a factor called "carbon intensity." Here, we clearly distinguish between the contribution of energy factors to carbon emission changes and also compare their relative importance to several other factors.

Second, we examine all factors over a ten-year time span, i.e., 1997, 2002, and 2007 MRIO tables $[17,18]$ (The 2007 table is the most recently published official MRIO table for China table). This longer period of analysis enables an investigation into how the various processes and factors evolved during China's growth spurt. This should enable insight into China's energy and emissions future.

Third, we decompose carbon emission change into three modules: (a) energy factors, (b) production factors, and (c) demand factors, altogether including 14 components across the three modules. This wealth of indicators at the regional level should supply much valuable information. We are particularly interested in questions that are seldom tackled in other analyses, like the extent to which change in the use of energy structure affects has altered the production of carbon emissions across the different regions of China. Such an inquiry should provide some insight into future energy transitions in China. We also try to analyze the role of interregional trade in emissions production. This should reveal $\mathrm{CO}_{2}$ flows within China and, thus, yield some suggestions to China's government on how to focus its $\mathrm{CO}_{2}$ reduction targets within its top-down system. Consistent with other studies, we hope to learn the main forces that are driving China's regional carbon emission increases and what abatement techniques are working best. But we do so within a more complete framework, i.e., considering factors from an energy focus-from both a supply-side and demand-side, which can reveal the relative contribution of public policies more precisely, at least insofar as proximate causation can be attributed. Finally, our contribution is particularly unique with respect to regional disparities and, hence, of most help for regional policy formation.

\section{Materials and Methods}

\subsection{Methods}

Focusing only on IDA, Choi and Ang (2003) found symmetry between multiplicative and additive decompositions in terms of shares and difference [19]. Ang and Zhang (2000) and Ang (2004) review the different IDA approaches in detail to find that, in most studies, the choice of multiplicative or additive decomposition is rather arbitrary [6,20]. They suggest some guidelines for identifying what type to use when. For example, they advocate for an additive decomposition when a quantity indicator is the object of the analysis and for a multiplicative decomposition when a ratio or share indicator is the object. They extend this suggestion to SDA [21,22]. That is, a ratio indicator is more conveniently handled with a multiplicative form, even though an additive SDA can handle the same set of factors [23-25]. Wang et al. (2017) find that equivalent results can be obtained for the two forms once a decomposition has been obtained using only one of them [26].

We follow Zhang and Lahr (2018) and apply a multiplicative SDA. We do so to address regional carbon emissions as opposed to energy use, which they examined [27]. Furthermore, we hope to study regional carbon intensity more deeply in the near future, so it also helps at the outset to develop a consistent, detailed research approach that has the potential to yield deep insight. This approach can consider the interdependence of industries, which is generally neglected in IDA. To begin, we define some terms. In this paper, $N$ denotes the number of industries per region, $R$ denotes the number of regions, $\mathrm{C}$ is the aggregate carbon emission (scalar), and $\mathbf{c}$ is the vector with $c_{i}^{j}$ as carbon emission per unit of output of industry $i$ in region $j(N R \times 1$ vector).

We can further decompose carbon emission per output $c^{\prime}$ into three factors:

$$
\mathbf{c}^{\prime}=\mathbf{c c}^{\prime} \times \mathbf{S} \times \mathbf{E},
$$

where: 
cc: Carbon emission coefficient whose element $c_{k}$ represents the carbon emission coefficient of fuel $k(k \times 1$ vector $)$;

S: Energy end-use structure matrix whose element $s_{k i}^{j}$ represents the ratio of amount of fuel $k$ consumed by sector $i$ in region $j(k \times N R$ matrix);

E: Energy intensity diagonal matrix whose diagonal element $e_{i i}$ represents the energy consumption per unit of gross output for each sector in each region $(N R \times N R$ matrix);

I: Identity matrix $(N R \times N R$ matrix $)$;

A: Matrix with input coefficients $\left(N R \times N R\right.$ matrix), with typical element $a_{i k}^{j s}$ denoting the input of product $i$ from region $j$ per unit of output in industry $k$ in region $s$;

L: Leontief-inverse matrix $(N R \times N R$ matrix $), \mathbf{L} \equiv(\mathbf{I}-\mathbf{A})^{-1}$;

F: Matrix of final demands for each region of destination $[N R \times(R+3)$ matrix], with typical element $f_{i}^{j s}$ denoting the final demand for commodity $i$ produced in region $j$ by region $s$ to produce $s=1,2, \ldots R . R+1$ denotes changes of inventories of commodity produced in region $j, R+2$ denotes export of commodity produced in region $j$, and $R+3$ denotes the other item, which is actually the error item to balance the input-output (I-O) table. Final demand includes urban consumption, rural consumption, and government consumption and investment. We aggregate these items because they have detailed regional information. The error (other) item has no apparent economic implication; we keep it here only to ensure the accuracy of the data;

f: Vector with element $f_{i}^{j}$ giving the final demand for output of industry $i$ in region $j(N R \times 1$ vector); $\mathbf{f}$ is the row sum of matrix $\mathbf{F}(\mathbf{f}=\mathbf{F h}$, where $\mathbf{h}$ is the $(R+3) \times 1$ summation vector consisting of ones.

We can further decompose $\mathbf{f}$ into two elements: $\mathbf{f}=\mathbf{B y}$, where $\mathbf{B}$ is the normalized final demand $[N R \times(R+3)$ matrix], where each cell is derived as the ratio of the corresponding cell in the final demand matrix to its respective column sum and $\mathbf{y}$ is the aggregate final demand for each of $(R+3)$ categories $[(R+3) \times 1$ vector $]$.

To make full use of the information of interregional flows for consumption and capital investment, we further decompose final demand into (i) a "bridge matrix" B that identifies expenditure shares separately for each of four final uses and (ii) a four-element vector of final demand totals $\mathbf{y}$. By final use they are represented, respectively, as matrices $\mathbf{B}^{\mathbf{c}}, \mathbf{B}^{\mathbf{i}}, \mathbf{B}^{\mathbf{x}}, \mathbf{B}^{\mathbf{o}}$ and vectors $\mathbf{y}^{\mathbf{c}}, \mathbf{y}^{\mathbf{i}}, \mathbf{y}^{\mathbf{x}}, \mathbf{y}^{\mathbf{o}}$. The superscript $c$ represents the sum of rural consumption, urban consumption, and government consumption and capital investment and $i$ represents changes in inventories, $x$ stands for exports, and $o$ represents others (error or discrepancy).

MRIO tables have detailed information about trade flows among regions both for intermediate transactions and for final demand. We expand our decomposition by introducing the following variables:

$\mathbf{A}^{*}$ : Matrix constructed by stacking $R$ identical $N \times N R$ matrices of aggregate intermediate inputs per unit of gross output by industry by region (NR $\times N R$ matrix), $\forall j:\left[a^{*}\right]=\sum_{j=1}^{R} a_{i k^{\prime}}^{j s}$

$\mathbf{T}^{\mathrm{A}}$ : Intermediate trade coefficients that show the input shares of each region in aggregated inputs by industry by region $(N R \times N R$ matrix $),\left[t^{A}\right]_{i k}^{j s}=a_{i k}^{j s} /\left[a^{*}\right]_{i k^{j}}^{j s}$; note that $\sum_{j}\left[t^{A}\right]_{i k}^{j s}=1$ and $\mathbf{A}=\mathbf{A}^{*} \circ \mathbf{T}^{\mathbf{A}}$, where $\circ$ denotes Hadamard product (element-by-element multiplication of matrices)

$\mathbf{A}^{*}$ can be further decomposed into two factors $\mathbf{A}^{\mathbf{T}}$ and $\mathbf{A}^{\mathbf{I}}$, that is, $\mathbf{A}^{*}=\mathbf{A}^{\mathrm{T}} \circ \mathbf{A}^{\mathrm{I}}$, where $\mathbf{A}^{\mathrm{T}}$ represents the technical coefficients that show the intermediate inputs structure (domestic and imported) and is constructed by stacking $N R$ identical $1 \times N R$ vectors of aggregated intermediate inputs per unit of gross output by industry by region as well as input of import per unit of gross output by industry by region $\left(N R \times N R\right.$ matrix), $\forall i, j:\left[a^{T}\right]=\sum_{i=1}^{N} \sum_{j=1}^{R} a_{i k}^{j s}+M_{k}^{s}$ (note: $M_{k}^{s}$ refers to the share of imported intermediate inputs to total inputs of industry $k$ at region $s$ and $\mathbf{A}^{\mathrm{I}}$ represents the substitution coefficients of imported inputs, showing the domestic input shares in aggregated intermediate inputs (domestic and imported) by industry by region (NR $\times N R$ matrix). $\left[a^{I}\right]_{i k}^{j s}=\left[a^{*}\right]_{i k}^{j s} /\left[a^{T}\right]$; 
We know that

$$
\begin{aligned}
& \mathbf{C}=\mathbf{c}^{\prime} \mathbf{L f}=\mathbf{c}^{\prime}(-\mathbf{A})^{-1} \mathbf{f}=\mathbf{c c}^{\prime} \operatorname{SE}(-\mathbf{A})^{-1} \mathbf{f} \\
& =\mathbf{c c}^{\prime} \operatorname{SE}\left(-\mathbf{A}^{*} \circ \mathbf{T}^{\mathbf{A}}\right)^{-1} \mathbf{B y} \\
& =\operatorname{cc}^{\prime} \operatorname{SE}\left(-\mathbf{A}^{\mathbf{T}} \circ \mathbf{A}^{\mathbf{I}} \circ \mathbf{T}^{\mathbf{A}}\right)^{-1}\left(\mathbf{B}^{\mathbf{c}} \mathbf{Y}^{\mathbf{c}}+\mathbf{B}^{\mathbf{i}} \mathbf{Y}^{\mathbf{i}}+\mathbf{B}^{\mathbf{x}} \mathbf{Y}^{\mathbf{x}}+\mathbf{B}^{\mathbf{o}} \mathbf{Y}^{\mathbf{o}}\right)
\end{aligned}
$$

Thus,

$$
\begin{aligned}
& =\frac{\frac{\mathrm{C}_{1}}{\mathrm{C}_{0}}}{\mathrm{cc}_{1}^{\prime} \mathbf{S}_{1} \mathbf{E}_{1} \mathbf{L}_{1} \mathbf{f}_{1}} \\
& \times \frac{\mathrm{cc}_{0}^{\prime} \mathbf{S}_{1} \mathrm{E}_{1} \mathbf{L}_{1} \mathbf{f}_{1}}{\mathrm{cc}_{0}^{\prime} \mathbf{S}_{0} \mathbf{E}_{1} \mathbf{L}_{1} \mathbf{f}_{1}} \\
& \times \frac{\mathbf{c c}_{0}^{\prime} \mathbf{S}_{0} \mathbf{E}_{1} \mathbf{L}_{1} \mathbf{f}_{1}}{\mathrm{cc}_{0}^{\prime} \mathbf{S}_{0} \mathbf{E}_{0} \mathbf{L}_{1} \mathbf{f}_{1}} \\
& \times \frac{\mathbf{c}_{0}^{\prime}\left(\mathbf{I}-\mathbf{A}_{1}^{T} \circ \mathbf{A}_{1}^{I} \circ \mathbf{T}_{1}^{A}\right)^{-1} \mathbf{f}_{1}}{\mathbf{c}_{0}^{\prime}\left(\mathbf{I}-\mathbf{A}_{0}^{T} \circ \mathbf{A}_{1}^{I} \circ \mathbf{T}_{1}^{A}\right)^{-1} \mathbf{f}_{1}} \\
& \times \frac{\mathbf{c}_{0}^{\prime}\left(\mathbf{I}-\mathbf{A}_{0}^{T} \circ \mathbf{A}_{1}^{I} \circ \mathbf{T}_{1}^{A}\right)^{-1} \mathbf{f}_{1}}{\mathbf{c}_{0}^{\prime}\left(\mathbf{I}-\mathbf{A}_{0}^{T} \circ \mathbf{A}_{0}^{I} \circ \mathbf{T}_{1}^{A}\right)^{-1} \mathbf{f}_{1}} \\
& \times \frac{\mathbf{c}_{0}^{\prime}\left(\mathbf{I}-\mathbf{A}_{0}^{T} \circ \mathbf{A}_{0}^{I} \circ \mathbf{T}_{1}^{A}\right)^{-1} \mathbf{f}_{1}}{\mathbf{c}_{0}^{\prime}\left(\mathbf{I}-\mathbf{A}_{0}^{T} \circ \mathbf{A}_{0}^{I} \circ \mathbf{T}_{0}^{A}\right)^{-1} \mathbf{f}_{1}} \\
& \times \frac{\mathbf{c}_{0}^{\prime} \mathbf{L}_{0}\left(\mathbf{B}_{1}^{\mathbf{c}} \mathbf{Y}_{1}^{\mathbf{c}}+\mathbf{B}_{1}^{\mathbf{i}} \mathbf{Y}_{1}^{\mathbf{i}}+\mathbf{B}_{1}^{\mathbf{x}} \mathbf{Y}_{1}^{\mathbf{x}}+\mathbf{B}_{1}^{\mathbf{o}} \mathbf{Y}_{1}^{\mathbf{o}}\right)}{\mathbf{c}_{0}^{\prime} \mathbf{L}_{0}\left(\mathbf{B}_{0}^{\mathbf{c}} \mathbf{Y}_{1}^{\mathbf{c}}+\mathbf{B}_{1}^{\mathbf{i}} \mathbf{Y}_{1}^{\mathbf{i}}+\mathbf{B}_{1}^{\mathbf{x}} \mathbf{Y}_{1}^{\mathbf{x}}+\mathbf{B}_{1}^{\mathbf{o}} \mathbf{Y}_{1}^{\mathbf{o}}\right)} \\
& \times \frac{\mathbf{c}_{0}^{\prime} \mathbf{L}_{0}\left(\mathbf{B}_{0}^{\mathbf{c}} \mathbf{Y}_{1}^{\mathbf{c}}+\mathbf{B}_{1}^{\mathbf{i}} \mathbf{Y}_{1}^{\mathbf{i}}+\mathbf{B}_{1}^{\mathbf{x}} \mathbf{Y}_{1}^{\mathbf{x}}+\mathbf{B}_{1}^{\mathbf{o}} \mathbf{Y}_{1}^{\mathbf{o}}\right)}{\mathbf{c}_{0}^{\prime} \mathbf{L}_{0}\left(\mathbf{B}_{0}^{\mathbf{c}} \mathbf{Y}_{0}^{\mathbf{c}}+\mathbf{B}_{1}^{\mathbf{i}} \mathbf{Y}_{1}^{\mathbf{i}}+\mathbf{B}_{1}^{\mathbf{x}} \mathbf{Y}_{1}^{\mathbf{x}}+\mathbf{B}_{1}^{\mathbf{o}} \mathbf{Y}_{1}^{\mathbf{o}}\right)} \\
& \times \frac{\mathbf{c}_{0}^{\prime} \mathbf{L}_{0}\left(\mathbf{B}_{0}^{\mathbf{c}} \mathbf{Y}_{0}^{\mathfrak{c}}+\mathbf{B}_{1}^{\mathbf{i}} \mathbf{Y}_{1}^{\mathbf{i}}+\mathbf{B}_{1}^{\mathbf{x}} \mathbf{Y}_{1}^{\mathbf{x}}+\mathbf{B}_{1}^{\mathbf{o}} \mathbf{Y}_{1}^{\mathbf{o}}\right)}{\mathbf{c}_{0}^{\prime} \mathbf{L}_{0}\left(\mathbf{B}_{0}^{\mathbf{c}} \mathbf{Y}_{0}^{\mathbf{c}}+\mathbf{B}_{0}^{\mathbf{i}} \mathbf{Y}_{1}^{\mathbf{i}}+\mathbf{B}_{1}^{\mathbf{x}} \mathbf{Y}_{1}^{\mathbf{x}}+\mathbf{B}_{1}^{\mathbf{o}} \mathbf{Y}_{1}^{\mathbf{o}}\right)} \\
& \times \frac{\mathbf{c}_{0}^{\prime} \mathbf{L}_{0}\left(\mathbf{B}_{0}^{\mathbf{c}} \mathbf{Y}_{0}^{\mathbf{c}}+\mathbf{B}_{0}^{\mathbf{i}} \mathbf{Y}_{1}^{\mathbf{i}}+\mathbf{B}_{1}^{\mathbf{x}} \mathbf{Y}_{1}^{\mathbf{x}}+\mathbf{B}_{1}^{\mathbf{o}} \mathbf{Y}_{1}^{\mathbf{o}}\right)}{\mathbf{c}_{0}^{\prime} \mathbf{L}_{0}\left(\mathbf{B}_{0}^{\mathbf{c}} \mathbf{Y}_{0}^{\mathbf{c}}+\mathbf{B}_{0}^{\mathbf{i}} \mathbf{Y}_{0}^{\mathbf{i}}+\mathbf{B}_{1}^{\mathbf{x}} \mathbf{Y}_{1}^{\mathbf{x}}+\mathbf{B}_{1}^{\mathbf{o}} \mathbf{Y}_{1}^{\mathbf{o}}\right)} \\
& \times \frac{\mathbf{c}_{0}^{\prime} \mathbf{L}_{0}\left(\mathbf{B}_{0}^{\mathbf{c}} \mathbf{Y}_{0}^{\mathbf{c}}+\mathbf{B}_{0}^{\mathrm{i}} \mathbf{Y}_{0}^{\mathbf{i}}+\mathbf{B}_{1}^{\mathbf{x}} \mathbf{Y}_{1}^{\mathbf{x}}+\mathbf{B}_{1}^{\mathbf{o}} \mathbf{Y}_{1}^{\mathbf{o}}\right)}{\mathbf{c}_{0}^{\prime} \mathbf{L}_{0}\left(\mathbf{B}_{0}^{\mathbf{c}} \mathbf{Y}_{0}^{\mathbf{c}}+\mathbf{B}_{0}^{\mathbf{i}} \mathbf{Y}_{0}^{\mathbf{i}}+\mathbf{B}_{0}^{\mathbf{x}} \mathbf{Y}_{1}^{\mathbf{x}}+\mathbf{B}_{1}^{\mathbf{o}} \mathbf{Y}_{1}^{\mathbf{o}}\right)} \\
& \times \frac{\mathbf{c}_{0}^{\prime} \mathbf{L}_{0}\left(\mathbf{B}_{0}^{\mathbf{c}} \mathbf{Y}_{0}^{\mathbf{c}}+\mathbf{B}_{0}^{\mathbf{i}} \mathbf{Y}_{0}^{\mathbf{i}}+\mathbf{B}_{0}^{\mathbf{x}} \mathbf{Y}_{1}^{\mathbf{x}}+\mathbf{B}_{1}^{\mathbf{o}} \mathbf{Y}_{1}^{\mathbf{o}}\right)}{\mathbf{c}_{0}^{\prime} \mathbf{L}_{0}\left(\mathbf{B}_{0}^{\mathbf{c}} \mathbf{Y}_{0}^{\mathbf{c}}+\mathbf{B}_{0}^{\mathbf{i}} \mathbf{Y}_{0}^{\mathbf{i}}+\mathbf{B}_{0}^{\mathbf{x}} \mathbf{Y}_{0}^{\mathbf{x}}+\mathbf{B}_{1}^{\mathbf{o}} \mathbf{Y}_{1}^{\mathbf{o}}\right)} \\
& \times \frac{\mathbf{c}_{0}^{\prime} \mathbf{L}_{0}\left(\mathbf{B}_{0}^{\mathbf{c}} \mathbf{Y}_{0}^{\mathbf{c}}+\mathbf{B}_{0}^{\mathbf{i}} \mathbf{Y}_{0}^{\mathbf{i}}+\mathbf{B}_{0}^{\mathbf{x}} \mathbf{Y}_{0}^{\mathbf{x}}+\mathbf{B}_{1}^{\mathbf{o}} \mathbf{Y}_{1}^{\mathbf{o}}\right)}{\mathbf{c}_{0}^{\prime} \mathbf{L}_{0}\left(\mathbf{B}_{0}^{\mathbf{c}} \mathbf{Y}_{0}^{\mathbf{c}}+\mathbf{B}_{0}^{\mathbf{i}} \mathbf{Y}_{0}^{\mathbf{i}}+\mathbf{B}_{0}^{\mathbf{x}} \mathbf{Y}_{0}^{\mathbf{x}}+\mathbf{B}_{0}^{\mathbf{o}} \mathbf{Y}_{1}^{\mathbf{o}}\right)} \\
& \times \frac{\mathbf{c}_{0}^{\prime} \mathbf{L}_{0}\left(\mathbf{B}_{0}^{\mathbf{c}} \mathbf{Y}_{0}^{\mathbf{c}}+\mathbf{B}_{0}^{\mathbf{i}} \mathbf{Y}_{0}^{\mathbf{i}}+\mathbf{B}_{0}^{\mathbf{x}} \mathbf{Y}_{0}^{\mathbf{x}}+\mathbf{B}_{0}^{\mathbf{o}} \mathbf{Y}_{1}^{\mathbf{o}}\right)}{\mathbf{c}_{0}^{\prime} \mathbf{L}_{0}\left(\mathbf{B}_{0}^{\mathbf{c}} \mathbf{Y}_{0}^{\mathbf{c}}+\mathbf{B}_{0}^{\mathbf{i}} \mathbf{Y}_{0}^{\mathbf{i}}+\mathbf{B}_{0}^{\mathbf{x}} \mathbf{Y}_{0}^{\mathbf{x}}+\mathbf{B}_{0}^{\mathbf{o}} \mathbf{Y}_{0}^{\mathbf{o}}\right)},
\end{aligned}
$$

where 0 represents the starting year and 1 denotes the ending year.

Carbon emission change can be decomposed into 14 partial effects (see Table 1): (2.1) denotes the effect of changes in carbon emission coefficient-in our analysis, we keep carbon emission coefficients constant across the period, thus, it has no contribution, so the following factors must remain the main forces driving carbon emission change; (2.2) denotes the effect of changes in energy end-use structure; 
(2.3) represents the effect of changes in energy intensity, that is, energy consumption per unit of gross output; (2.4) measures the effect of changes in intermediate input structure (technology effect); (2.5) represents the effect of changes in import substitution of production structure; (2.6) shows the structure effect of changed interregional trade in intermediate inputs; (2.7) denotes the effect of changes in composition of consumption and capital; (2.8) gives the effect of changes in level of consumption; similarly, (2.9) and (2.10) represent the effect of changes in composition and level of inventories changes, respectively; (2.11) and (2.12) show the effects of changes due to export structure and level; and (2.13) and (2.14) are for error items. It is alternatively called "discrepancy" by national statistical agencies. It is a line item that expedites balancing of I-O accounts. It does not have any apparent economic meaning and is, fortunately, consistently very small and, hence, insignificant in the overall scheme of things. When we decompose for each region, we replace the vector $c^{\prime}$ by diagonal matrices with the same elements on the main diagonal and zeroes elsewhere and pre-multiply all numerators and denominators with $(N R \times N R)$ region aggregation vectors, one for each region.

Table 1. Definition of notation.

\begin{tabular}{llll}
\hline Notation & & & Definition \\
\hline Energy factors & $\mathbf{c c}$ & 1 & Carbon emission coefficient \\
& $\mathbf{S}$ & 2 & Energy end-use structure \\
& $\mathbf{E}$ & 3 & Energy Intensity \\
\hline Production pattern & $\mathbf{A}^{\mathbf{T}}$ & 4 & Intermediate input structure \\
& $\mathbf{A}^{\mathbf{I}}$ & 5 & Import substitution (domestic supply ratio) \\
& $\mathbf{T}^{\mathbf{A}}$ & 6 & Interregional trade in intermediate input \\
\hline Demand pattern & $\mathbf{B}^{\mathbf{c}}$ & 7 & Composition of consumption and capital \\
& $\mathbf{Y}^{\mathbf{c}}$ & 8 & Level of consumption and capital \\
& $\mathbf{B}^{\mathbf{i}}$ & 9 & Composition of inventories \\
& $\mathbf{Y}^{\mathbf{i}}$ & 10 & Level of inventories \\
& $\mathbf{B}^{\mathbf{x}}$ & 11 & Composition of export \\
& $\mathbf{Y}^{\mathbf{x}}$ & 12 & Level of export \\
& $\mathbf{B}^{\mathbf{0}}$ & 13 & Composition of others (error term) \\
& $\mathbf{Y}^{\mathbf{0}}$ & 14 & Level of others (error term) \\
\hline
\end{tabular}

We also develop a decomposition that is the polar opposite to the one identified above. In any case, our final decomposition result is the geometric average (Fisher index) of two polar decompositions, which, according to Dietzenbacher and Los (1998) [28], is very close to the average of all possible decompositions. We understand that the geometric mean of all decompositions is better than using the mean of the two polar decompositions (Dietzenbacher and Los, 1998 [28]). Also, at least in theory, the Sato-Vartia ideal decomposition (De Boer, 2009a,b) seems better than the geometric mean of the polar decompositions $[29,30]$. However, the former approach demands obtaining solutions to all 14 elementary decompositions and the latter requires an extension to 14 factors. Both require substantially more effort with no guarantee of a substantially improved result. The extension to a Sato-Vartia decomposition at least is beyond the scope of the present piece.

There are some issues we should mention or some aspects that are missing in this paper that deserve attention in the near future. Some determinants in this equation are potentially collinear and such apparent dependencies can induce some bias in the results of decomposition analyses [31]. But as Dietzenbacher, Lahr, and Los (2004) point out, the remedy could be worse than the disease when analyzing such a complex issue, so we choose not to correct for such potential dependencies here [32]. Further, Guan et al. (2012) and Liu et al. (2015) worry about uncertainty in Chinese emissions data $[33,34]$. In the present paper, we use provincial energy consumption data for two reasons: First, high-quality data with provincial detail are not reported in the national statistical system, which remains the only truly reliable data repository in China. This likely also explains why it continues to be used by so many researchers (c.f., Zhang and Lahr (2018) and Feng at al. (2013) [13,27]). Second, our 
focus on factors' relative contributions to emissions change over a specific period softens the seriousness of such data issues to some extent. Nonetheless, if other reliable sources should arise, an analysis like this can be redone and enrich this line of research.

\subsection{Materials}

\subsubsection{Data Source}

The main data are 1997 (China National Information Center, 2005), 2002, and 2007 MRIO tables [17,18], provincial final energy consumption data by industry [35-37], and $\mathrm{CO}_{2}$ emission factors. In this analysis, the 2007 MRIO table is the latest and all three tables we use are fortunately comparable since they are compiled by the same team. Unlike other national data, it typically takes many years to collect data and thoroughly balance the I-O accounts. Nonetheless, we contend that our present analysis will yield some valuable insight that could assist in China's carbon abatement programs. We perform a dynamic analysis on China's regional carbon emission change across ten years using the latest official, published data. Such a historical review can help us all to better understand the carbon abatement potential for each factor we employ in our analysis; it can be a foundation for formulating present and future policies. In this vein, I-O analysis is a coarse forecasting tool. With all of this in mind, our analysis could also inform feasible policies instruments for today's practice.

\subsubsection{Data Compilation}

\section{Deflation of Tables}

Since I-O tables are in value terms and both MRIO tables are in nominal prices, we adjusted the values in an attempt to eliminate price effects. We inflated the 1997 and $2002 \mathrm{I}-\mathrm{O}$ tables to make their values consistent with those in 2007. This enabled us to use data in prices to which the reader can best relate, i.e., in prices of the most recent year's in our data. The biproportional-adjustment technique RAS is commonly used, at least in academic literature, toward such ends [38]. For the deflators, please see [39]. The 1997 MRIO table was published in 2005. We used different deflators for different industries. For some industries, the deflator even came from finer industries, with value added as weight. The 2002 and 2007 MRIO tables were published in 2012 by the same authors. The tables have the same categories for industries and regions. Table 2 shows the detailed information for the eight regions. Note, there are two minor differences between the 1997 MRIO and the 2002 and 2007 MRIO tables, which we have adjusted according to [40] (We omitted the detailed data processing for space limitation, but we are glad to provide all these materials upon request).

Table 2. Regional classifications.

\begin{tabular}{ll}
\hline \multicolumn{1}{c}{ Region } & Provinces (Municipalities) \\
\hline North East (NE) & Liaoning, Jilin, Heilongjiang \\
North Municipalities (NM) & Beijing, Tianjin \\
North Coast (NC) & Hebei, Shandong \\
East China (EC) & Shanghai, Jiangsu, Zhejiang \\
South China (SC) & Guangdong, Fujian, Hainan \\
Central China (CC) & Shanxi, Henan, Anhui, Hubei, Hunan, Jiangxi \\
Northwest China (NW) & Shaanxi, Gansu, Ningxia, Qinghai, Xinjiang, Inner Mongolia \\
Southwest China (SW) & Sichuan, Chongqing, Guizhou, Yunnan, Guangxi, Tibet \\
\hline
\end{tabular}

\section{Construction of Trade Coefficients}

Referring to the construction of the trade coefficient matrices for intermediate transaction matrix, we assign the trade coefficient to be zero when the use of an industry's output by an industry is zero; we assign the same value as the corresponding trade coefficient for the other year when the total use was zero in one year but positive in the other. This implies in these situations that all carbon emission 
changes will be attributed to changes in the input structure and none to changes in trade structure when all other values remain equal.

\section{Carbon Coefficients}

The final energy consumption data are from the energy year book in corresponding years. When we calculate the energy structure for each industry, so we need to transform all fuels types into a single set of physical units-standard coal equivalents. To make all data comparable, we also calculate the carbon emission coefficient per standard coal equivalent by fuel type (see Table 3).

Table 3. Carbon emission coefficient for fuels.

\begin{tabular}{cccc}
\hline No. & Name & $\begin{array}{c}\text { Carbon Emission } \\
\text { Coefficient (Physical Unit) }\end{array}$ & $\begin{array}{c}\text { Carbon Emission Coefficient } \\
\text { (Standard Coal Equivalent) }\end{array}$ \\
\hline 1 & Raw coal & $1.978 \mathrm{~kg} / \mathrm{kg}$ & $2.769 \mathrm{~kg} / \mathrm{kg}$ \\
2 & Cleaned coal & $2.492 \mathrm{~kg} / \mathrm{kg}$ & $2.769 \mathrm{~kg} / \mathrm{kg}$ \\
3 & Other washed coal & $0.791 \mathrm{~kg} / \mathrm{kg}$ & $2.769 \mathrm{~kg} / \mathrm{kg}$ \\
4 & Briquettes & $1.825 \mathrm{~kg} / \mathrm{kg}$ & $2.555 \mathrm{~kg} / \mathrm{kg}$ \\
5 & Coke & $3.042 \mathrm{~kg} / \mathrm{kg}$ & $3.132 \mathrm{~kg} / \mathrm{kg}$ \\
6 & Coke oven gas & $0.742 \mathrm{~kg} / \mathrm{m}^{3}$ & $1.299 \mathrm{~kg} / \mathrm{kg}$ \\
7 & Other gas & $0.232 \mathrm{~kg} / \mathrm{m}^{3}$ & $1.299 \mathrm{~kg} / \mathrm{kg}$ \\
8 & Crude oil & $3.065 \mathrm{~kg} / \mathrm{kg}$ & $2.146 \mathrm{~kg} / \mathrm{kg}$ \\
9 & Gasoline & $2.985 \mathrm{~kg} / \mathrm{kg}$ & $2.029 \mathrm{~kg} / \mathrm{kg}$ \\
10 & Kerosene & $3.097 \mathrm{~kg} / \mathrm{kg}$ & $2.105 \mathrm{~kg} / \mathrm{kg}$ \\
11 & Diesel oil & $3.167 \mathrm{~kg} / \mathrm{kg}$ & $2.169 \mathrm{~kg} / \mathrm{kg}$ \\
12 & Fuel oil & $3.237 \mathrm{~kg} / \mathrm{kg}$ & $2.266 \mathrm{~kg} / \mathrm{kg}$ \\
13 & PLG & $3.1667 \mathrm{~kg} / \mathrm{kg}$ & $1.847 \mathrm{~kg} / \mathrm{kg}$ \\
14 & Refinery gas & $2.653 \mathrm{~kg} / \mathrm{kg}$ & $1.688 \mathrm{~kg} / \mathrm{kg}$ \\
15 & Natural gas & $2.184 \mathrm{~kg} / \mathrm{cu} \cdot \mathrm{m}$ & $1.643 \mathrm{~kg} / \mathrm{kg}$ \\
16 & Other petroleum product & $3.065 \mathrm{~kg} / \mathrm{kg}$ & $2.146 \mathrm{~kg} / \mathrm{kg}$ \\
17 & Other coking products & $3.043 \mathrm{~kg} / \mathrm{kg}$ & $3.132 \mathrm{~kg} / \mathrm{kg}$ \\
\hline
\end{tabular}

Note: Electricity and heating are produced by above fuels, to avoid double counting of carbon emissions, we assume their carbon emission coefficients are zero.

In this paper, we use original IPCC (Intergovernmental Panel on Climate Change) coefficients, but we also use China's calorific values to get an adjusted emission coefficient [41]. As we attempt to compare the relative effect of the various drivers of China's regional emission change, not the absolute level of emissions, consistency of the data and method is more important than perfect accuracy with respect to the energy content of coal in China.

At the regional level, however, energy use is included in five sectors. To preserve as much information as possible, we only aggregated further to five sectors when performing an operation with energy data (see Table 4 for detailed sector information). 
Table 4. Industrial Classifications.

\begin{tabular}{clll}
\hline No. & Name & \multicolumn{1}{c}{ Category 1 } & \multicolumn{1}{c}{ Category 2 } \\
\hline 1 & AGRI & Agriculture & Agricultures \\
2 & INDU & Industry & Mining \\
& & & Food products \\
& & Textile and wearing apparel \\
& & & Wooden products \\
& & & Paper and printing \\
& & & Chemical products \\
& & & Non-metallic mineral products \\
& & & Metal products \\
& & & Machinery \\
& & & Transportation equipment \\
& & & Electronic products \\
& & & Other manufacturing products \\
& & & Electricity, gas, and water supply \\
3 & CONS & Construction & Construction \\
4 & TRAD & Trade and transport & Trade and transport \\
5 & SERV & Services & Services \\
\hline
\end{tabular}

Note: Category 1 is based upon energy balance table by province (municipality, autonomous district). Category 2 is derived from China's MRIO tables.

\section{Result}

\subsection{Descriptive Statistics}

From 1997 to 2007, carbon emissions in China soared, particularly during the second half. The growth rate rose from 3.2 to 13.3 percent during the two periods, leading to about 3.9 billion tons of $\mathrm{CO}_{2}$ emission in 2007 (please see Figures 1 and 2). The situation varied across regions. We found emissions on the north coast rose fastest with an average annual rate of 12.2 from 1997 to 2007, while central China contributed the largest share of China's emissions in 2007. On the contrary, north municipalities offered the lowest level of emissions and, during 1997 to 2002, their emissions even decreased, despite rapid economic growth.

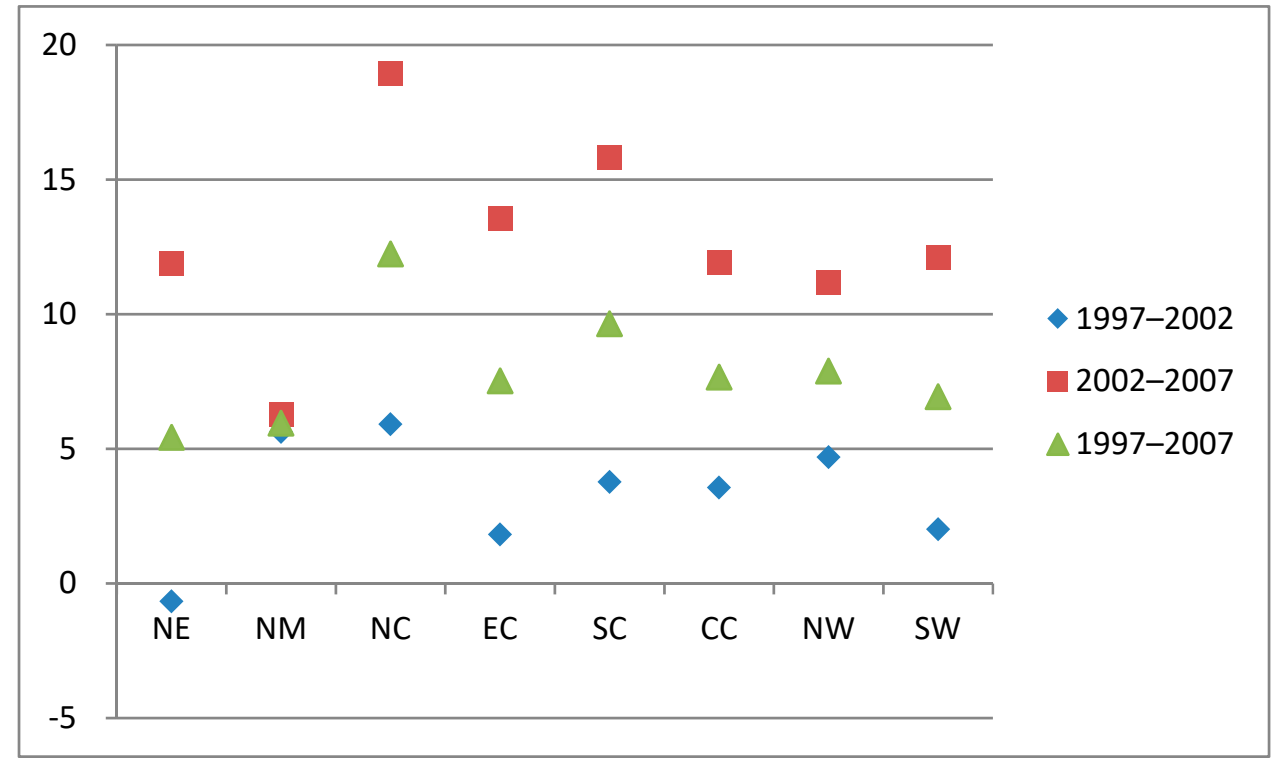

Figure 1. Annualized growth rate by region. 


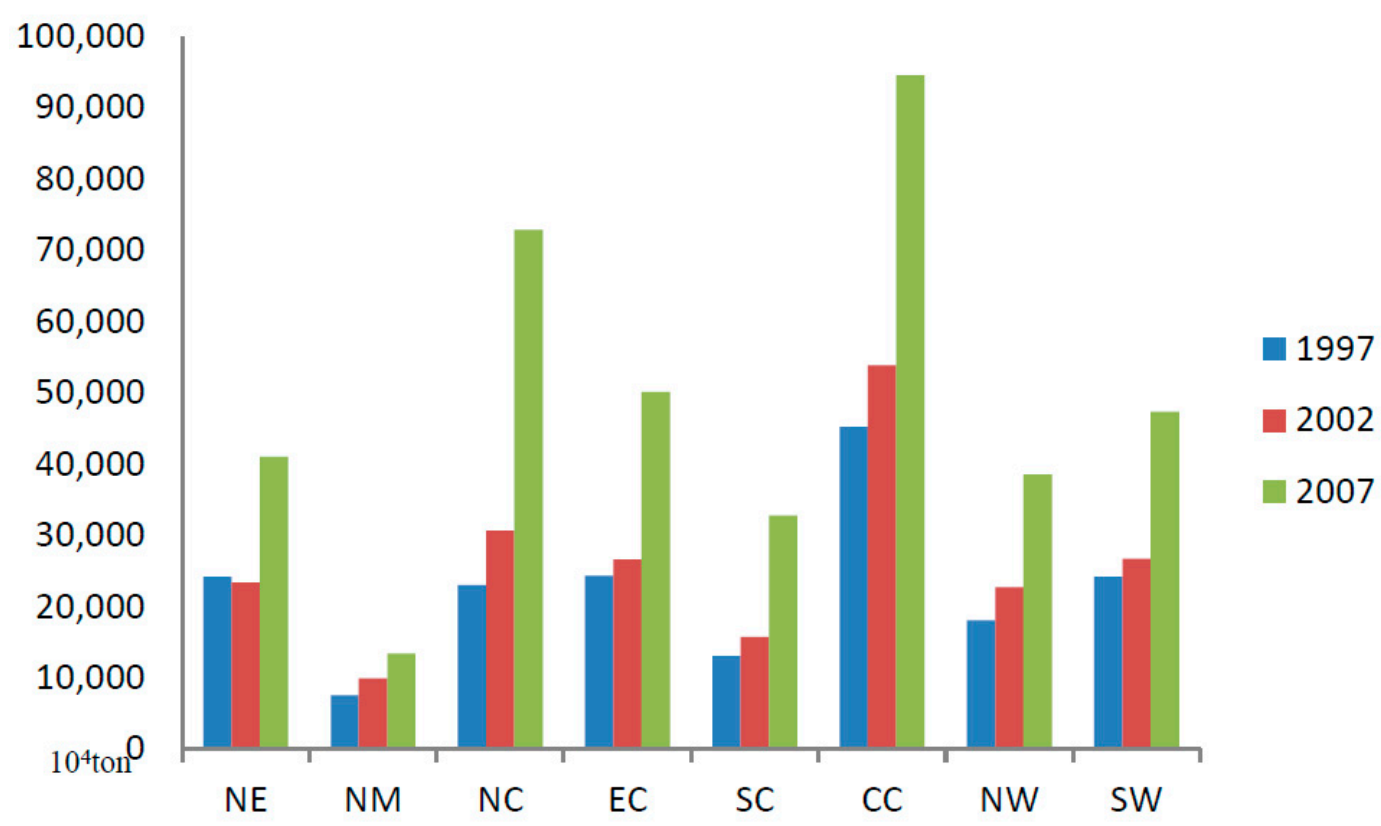

Figure 2. Regional carbon emissions: 1997-2007.

Up to this point, we have attempted to reveal a general understanding of temporal and spatial variations regarding China's $\mathrm{CO}_{2}$ emissions. The following structural decomposition analysis yields a deeper perspective on the driving forces behind their changes.

\subsection{Structural Decomposition Analysis (SDA) for $\mathrm{CO}_{2}$ Emission}

We categorize all the factors into three groups and the analysis below is accordingly based on this classification. The first group is mainly energy factors and includes energy-use structure and energy intensity. In this paper, the emissions are calculated according to end-use energy consumption by sector. The second group focuses on the supply side, which focuses more in the industry mix and input mix. The third group concentrates on the demand side, particularly on the expenditure structure and relative levels of final demand.

\subsubsection{Energy Factors}

The energy factors include energy structure and energy intensity. During the whole period, the change of energy consumption structure decreases China's $\mathrm{CO}_{2}$ emission slightly. However, in most regions, energy structure contributed to emission reduction, particularly over the 1997-2002 period. However, in the north municipalities it played a most important role in total emissions reduction (see Table 5 for the decomposition result). In 1997, the region consumed about $30 \%$ coal and $20 \%$ coke and these fuels produce much more $\mathrm{CO}_{2}$ emissions than do other fuels (see Table 3 for the last column). By 2002 , the northern municipalities fuel mix was just $20 \%$ coal and $12 \%$ coke and instead consumed more natural gas, other gas, refinery gas, and other petroleum gas. This change in fuel mix greatly reduced their carbon emissions from 1997 to 2002. Other regions also reduced their coal consumption, resulting in a negative effect on emissions. We ask readers to pay particular attention to central China, where energy consumption structure had a positive effect from 1997 to 2002, but the largest negative effect from 2002 to 2007. Coal's share of the fuel mix in this region accounted for more than half of its total energy use; accordingly, central China has a greater potential to change its energy structure and thus carbon abatement. 
Table 5. Carbon emission result in the 1997-2002 period.

\begin{tabular}{|c|c|c|c|c|c|c|c|c|c|c|c|c|c|c|}
\hline \multirow[t]{2}{*}{ Region } & \multicolumn{2}{|c|}{ Energy Factors } & \multicolumn{3}{|c|}{ Production Pattern } & \multicolumn{6}{|c|}{ Demand Pattern } & \multicolumn{3}{|r|}{ Total } \\
\hline & $\begin{array}{l}\text { Energy } \\
\text { Structure } \\
(\%)\end{array}$ & $\begin{array}{l}\text { Energy } \\
\text { Intensity } \\
(\%)\end{array}$ & $\begin{array}{l}\text { Production } \\
\text { Technology } \\
(\%)\end{array}$ & $\begin{array}{l}\text { Domestic } \\
\text { Supply } \\
(\%)\end{array}$ & $\begin{array}{c}\text { Interregional } \\
\text { Trade } \\
(\%)\end{array}$ & $\begin{array}{l}\text { Consumption } \\
\text { and Capital } \\
\text { Structure (\%) }\end{array}$ & $\begin{array}{l}\text { Consumption } \\
\text { and Capital } \\
\text { Level (\%) }\end{array}$ & $\begin{array}{l}\text { Inventory } \\
\text { Structure } \\
\quad(\%)\end{array}$ & $\begin{array}{c}\text { Inventory } \\
\text { Level } \\
(\%)\end{array}$ & $\begin{array}{l}\text { Export } \\
\text { Structure } \\
(\%)\end{array}$ & $\begin{array}{l}\text { Export } \\
\text { Level } \\
(\%)\end{array}$ & $\begin{array}{l}\text { "Other" } \\
\text { Structure } \\
(\%)\end{array}$ & $\begin{array}{l}\text { "Other" } \\
\text { Level } \\
(\%)\end{array}$ & $(\%)$ \\
\hline $\mathrm{NE}$ & -2 & -39 & -13 & -9 & 9 & 3 & 42 & -2 & -1 & -2 & 9 & 0 & 1 & -3 \\
\hline NM & -6 & -23 & -2 & 6 & -28 & -8 & 43 & 20 & -6 & 1 & 15 & -6 & 21 & 27 \\
\hline NC & 0 & -17 & -6 & -3 & -27 & -8 & 41 & 8 & -4 & 2 & 9 & -12 & 45 & 29 \\
\hline $\mathrm{EC}$ & -2 & -36 & -6 & -6 & 11 & -2 & 33 & -1 & -1 & 4 & 18 & 1 & -3 & 9 \\
\hline SC & -1 & -41 & -5 & -9 & 15 & 1 & 31 & -12 & 2 & 1 & 27 & 1 & 9 & 19 \\
\hline CC & 1 & -27 & -10 & -12 & -12 & -6 & 46 & 5 & -3 & 0 & 7 & 4 & 24 & 18 \\
\hline NW & -2 & -20 & -4 & 0 & -11 & -1 & 47 & 5 & -3 & 0 & 6 & -3 & 10 & 23 \\
\hline SW & -1 & -21 & -4 & -2 & 9 & 0 & 47 & -31 & 6 & 1 & 6 & 0 & 0 & 10 \\
\hline China & -1 & -28 & -7 & -6 & -4 & -3 & 42 & -1 & -1 & 1 & 10 & 1 & 14 & 16 \\
\hline
\end{tabular}

Note: 1 . As the "other" item in final demand does not have any economic implications, we do not report its decomposition result. Accordingly, the total result approximates the sum of all listed factors. 2. "Total" refers to changes in $\mathrm{CO}_{2}$ emission in the 1997-2002 period.

Table 6. Carbon emission results in the 2002-2007 period.

\begin{tabular}{|c|c|c|c|c|c|c|c|c|c|c|c|c|c|c|}
\hline \multirow[t]{2}{*}{ Region } & \multicolumn{2}{|c|}{ Energy Factors } & \multicolumn{3}{|c|}{ Production Pattern } & \multicolumn{6}{|c|}{ Demand Pattern } & \multicolumn{3}{|r|}{ Total } \\
\hline & $\begin{array}{l}\text { Energy } \\
\text { Structure } \\
(\%)\end{array}$ & $\begin{array}{c}\text { Energy } \\
\text { Intensity } \\
(\%)\end{array}$ & $\begin{array}{c}\text { Production } \\
\text { Technology } \\
\text { (\%) }\end{array}$ & $\begin{array}{l}\text { Domestic } \\
\text { Supply } \\
(\%)\end{array}$ & $\begin{array}{l}\text { Interregional } \\
\text { Trade (\%) }\end{array}$ & $\begin{array}{l}\text { Consumption } \\
\text { and Capital } \\
\text { Structure (\%) }\end{array}$ & $\begin{array}{l}\text { Consumption } \\
\text { and Capital } \\
\text { Level (\%) }\end{array}$ & $\begin{array}{c}\text { Inventory } \\
\text { Structure } \\
(\%)\end{array}$ & $\begin{array}{l}\text { Inventory } \\
\text { Level } \\
(\%)\end{array}$ & $\begin{array}{l}\text { Export } \\
\text { Structure } \\
(\%)\end{array}$ & $\begin{array}{l}\text { Export } \\
\text { Level } \\
(\%)\end{array}$ & $\begin{array}{l}\text { “Other" } \\
\text { Structure } \\
\quad(\%)\end{array}$ & $\begin{array}{l}\text { "Other" } \\
\text { Level } \\
(\%)\end{array}$ & $(\%)$ \\
\hline $\mathrm{NE}$ & 0 & -16 & 9 & 0 & 5 & 8 & 32 & 1 & 1 & 0 & 19 & -3 & 0 & 56 \\
\hline NM & 1 & -57 & 6 & 1 & 16 & 18 & 25 & -21 & 15 & 5 & 31 & -17 & 8 & 30 \\
\hline $\mathrm{NC}$ & 1 & -18 & 10 & 7 & 16 & 6 & 39 & -6 & 12 & 0 & 18 & -12 & 13 & 87 \\
\hline EC & 0 & -23 & 5 & 4 & -15 & 5 & 38 & 0 & 1 & 10 & 40 & 0 & -2 & 64 \\
\hline SC & -1 & -3 & 2 & 10 & -2 & 10 & 28 & 11 & -8 & -17 & 45 & -2 & 2 & 74 \\
\hline $\mathrm{CC}$ & -3 & -29 & 9 & 7 & -2 & -5 & 41 & 0 & 12 & 1 & 12 & 9 & 5 & 56 \\
\hline NW & -1 & -41 & 6 & -1 & 32 & 11 & 28 & -8 & 8 & 11 & 18 & -14 & 3 & 53 \\
\hline SW & 1 & -29 & 7 & 3 & -10 & 1 & 40 & 47 & -27 & -1 & 13 & 12 & 1 & 57 \\
\hline China & 0 & -25 & 7 & 4 & 3 & 4 & 36 & 3 & 4 & 1 & 22 & 0 & 4 & 62 \\
\hline
\end{tabular}

Note: 1. As the "other" item in final demand does not have any economic implication, we do not report its decomposition result. Accordingly, the total result approximates the sum of all listed factors. 2. "Total" refers to changes in $\mathrm{CO}_{2}$ emission in the 2002-2007 period. 
Table 7. Carbon emission results in the 1997-2007 period.

\begin{tabular}{|c|c|c|c|c|c|c|c|c|c|c|c|c|c|c|}
\hline \multirow[t]{2}{*}{ Region } & \multicolumn{2}{|c|}{ Energy Factors } & \multicolumn{3}{|c|}{ Production Pattern } & \multicolumn{6}{|c|}{ Demand Pattern } & \multicolumn{3}{|r|}{ Total } \\
\hline & $\begin{array}{l}\text { Energy } \\
\text { Structure } \\
(\%)\end{array}$ & $\begin{array}{c}\text { Energy } \\
\text { Intensity } \\
(\%)\end{array}$ & $\begin{array}{l}\text { Production } \\
\text { Technology } \\
(\%)\end{array}$ & $\begin{array}{l}\text { Domestic } \\
\text { Supply } \\
(\%)\end{array}$ & $\begin{array}{c}\text { Interregional } \\
\text { Trade (\%) }\end{array}$ & $\begin{array}{l}\text { Consumption } \\
\text { and Capital } \\
\text { Structure (\%) }\end{array}$ & $\begin{array}{l}\text { Consumption } \\
\text { and Capital } \\
\text { Level (\%) }\end{array}$ & $\begin{array}{l}\text { Inventory } \\
\text { Structure } \\
(\%)\end{array}$ & $\begin{array}{l}\text { Inventory } \\
\text { Level } \\
(\%)\end{array}$ & $\begin{array}{l}\text { Export } \\
\text { Structure } \\
(\%)\end{array}$ & $\begin{array}{l}\text { Export } \\
\text { Level } \\
(\%)\end{array}$ & $\begin{array}{l}\text { “Other" } \\
\text { Structure } \\
(\%)\end{array}$ & $\begin{array}{l}\text { “Other" } \\
\text { Level } \\
(\%)\end{array}$ & $(\%)$ \\
\hline NE & -1 & -55 & -4 & -6 & 12 & 10 & 70 & -2 & 3 & -3 & 35 & -5 & 0 & 53 \\
\hline NM & -5 & -82 & 4 & 1 & -7 & 15 & 69 & 0 & 2 & 6 & 54 & 0 & -1 & 58 \\
\hline NC & 1 & -35 & 5 & 4 & -11 & 1 & 82 & 3 & 6 & 4 & 30 & 1 & 27 & 115 \\
\hline $\mathrm{EC}$ & -2 & -61 & -1 & 0 & -5 & 3 & 66 & -2 & 2 & 16 & 62 & -3 & -2 & 73 \\
\hline SC & -3 & -45 & -4 & 2 & 13 & 11 & 59 & -5 & 1 & -16 & 71 & -2 & 10 & 92 \\
\hline $\mathrm{CC}$ & -1 & -57 & -1 & -3 & -14 & -12 & 86 & 7 & 7 & 2 & 22 & 0 & 38 & 74 \\
\hline NW & -3 & -60 & 0 & -5 & 23 & 11 & 71 & -1 & 4 & 12 & 31 & -6 & 0 & 76 \\
\hline SW & 0 & -51 & 2 & -1 & 0 & 0 & 73 & 4 & 5 & 1 & 19 & 5 & 11 & 67 \\
\hline China & -1 & -55 & 0 & -1 & -1 & 1 & 74 & 2 & 4 & 1 & 35 & 0 & 16 & 75 \\
\hline
\end{tabular}

Note: 1. As the "other" item in final demand does not have any economic implications, we do not report its decomposition result. Accordingly, the total result approximates the sum of all listed factors. 2. "Total" refers to changes in $\mathrm{CO}_{2}$ emissions in the 1997-2007 period. 
China's energy production structure has not changed much since the 1990s, that is, coal production accounts for about $78-80 \%$, oil about $10-17 \%$, and gas $2-4 \%$ [35]. The nation's energy consumption structure is decided to a large extent on the pattern of available energy resource supply. From the regional perspective, Shanxi, Shaanxi, Inner Mongolia, Henan, Guizhou, and Shandong produced most of China's coal. This partly explains why the north coast and the central coast are reluctant to transform their energy fuel mix.

On the other hand, energy intensity improvements were a main contributor to carbon emission reduction across all regions, although it appears to have been offset by the final demand factors in both periods. We discuss this in more detail later. Energy intensity greatly reduced $\mathrm{CO}_{2}$ emission in south, northeast, and east China from 1997 to 2002 and in north municipalities and northwest China from 2002 to 2007. Garbaccio et al. (1999) and Fisher-Vanden et al. (2004) showed that technology progress and $R$ \& $D$ inputs drive China's progress in energy intensity $[42,43]$. We believe they are largely behind the tremendous energy intensity improvements in south China and east China. After Xiaoping Deng's speech in 1992, China's government has given eastern coastal areas preferential policy for foreign investment. This in turn has promoted coastal development both in technology and management; since then, energy has been used more efficiently. Industry upgrading also has led to improvements in energy intensity in north municipalities. By transferring traditional industries out of Beijing and Tianjin, the region concentrates more on tertiary sector and becomes less energy required. When observing northeast (1997-2002) and northwest China (2002-2007), we find both achieved great efficiency improvements in the industry when compared to other regions. Particularly in northeast China, Liaoning province played a leading role.

\subsubsection{Production Pattern}

Changes in production technology reflect changes in the interindustry structure (due to technological change, factor substitution, changing output compositions within industries, etc.) on changes in $\mathrm{CO}_{2}$ emission. From 1997 to 2002, the change led to $\mathrm{CO}_{2}$ emission reduction in all regions. This suggests that the new technologies enabled the more production with fewer $\mathrm{CO}_{2}$ emissions. However, from 2002 to 2007, this phenomenon reversed.

The domestic supply ratio in intermediate production can be defined as the material replacement effect of the production process from imports. When the domestic supply ratio of intermediate input rises, the energy input in production naturally increases; accordingly, production enables more $\mathrm{CO}_{2}$ emissions, given all else remains unchanged. It also can be easily understood from an import perspective, since increasing the share of imports used certainly reduces $\mathrm{CO}_{2}$ emissions, at least from a production liability perspective (i.e., the pollution is essentially exported). The import substitution reduced $\mathrm{CO}_{2}$ emission in all regions except north municipalities and northwest China in 1997-2002 but, in the second five-year period, a larger domestic supply ratio means more carbon emissions were produced. This was the case in all regions except northeast and northwest China.

Interregional trade in intermediate inputs had significant influence on emission reduction in north municipalities and the north coast in 1997-2002. This shift means that more inputs were supplied from other regions (apparent pollution havens); by exploiting this possibility the north municipalities and the north coast were able to reduce their own emissions. Among all the factors, its absolute influence ranks second for these two regions. In the 2002-2007 period, however, emissions in east China and southwest China declined substantially via this factor.

\subsubsection{Demand Pattern}

\section{Level Effect}

We have reported six factors in demand patterns in Table 5, Table 6, and Table 7. These factors can be categorized into two groups: A structure effect and a level effect. It is not surprising that all level effects play a major role in emission growth. Deeper observations suggest that total urban consumption 
and government consumption increased 2.18 and 1.9 times, respectively, in 2002 from 1997. From 2002 to 2007, exports and capital investment became the main drivers of emission growth, where the former increased 2.69 times and the latter 2.05 times. This is clearly reflected in our decomposition result. In the 2002-2007 period, the level of export growth alone contributed more than half of all emission growth compared with the sum of rural, urban, government consumption and capital investment. It can be easily inferred that a big part of China's $\mathrm{CO}_{2}$ emission growth is due to consumption by the other countries. Although all regions had different performances in terms of changes in final demand level, they shared the general upward trend.

\section{Structural Effect}

It is not surprising that for such a big developing country like China, the level of final demand expanded rapidly. It might be more interesting to take a close look at the change in final demand structure. A major advantage of MRIO tables is that they include interregional flow information; thus, we can analyze the effect of change in interregional trade to $\mathrm{CO}_{2}$ emissions. We choose to use a bridge matrix (i.e., the structure of final demand-a catenation of the matrices $\mathbf{B}^{\mathbf{c}}, \mathbf{B}^{\mathbf{i}}, \mathbf{B}^{\mathbf{x}}, \mathbf{B}^{\mathbf{o}}$ ) in our analysis because we are particularly interested in emissions caused by final demand across the different regions and such a matrix can display the change in a vivid way. The final-demand bridge matrix shows the structure of consumption bundles in final demand. More importantly, when analysis is performed at a regional level, we can easily derive how a $1 \%$ change in one region's demand is satisfied by production that emits carbon in other regions. In essence, we can learn how the change in interregional trade affects emissions.

From 1997 to 2007, each region tended to be the main supplier of its own final demand, but this gradually changed soon after. In 1997, each region contributed over 90 percent of its total final demand in consumption and capital investment. The biggest self-sufficiency ratio was $95 \%$ for the north coast and the smallest self-sufficiency ratio is $90 \%$ for northwest China. While in 2002, all other regions still keep the ratio ranging from $85 \%$ to $96 \%$, except north municipalities, which had a self-sufficiency ratio of $79 \%$. Through 2007, change was rather fundamental; all regions' self-sufficiency declined to between $71 \%$ and $87 \%$. That is, northwest China only produced $71 \%$ of the final demand that it needed, whereas northeast had $13 \%$ of its final demand met by other regions.

To make it clearer, we present the bridge matrix change during 1997-2002 and 2002-2007, respectively, in Tables 8 and 9 at the regional level. The diagonal elements in the table list the changes in the self-sufficiency ratio. Not surprisingly, $\mathrm{CO}_{2}$ emissions of most regions declined from 1997 to 2002 as most regions reduced their self-sufficiency ratio to some extent. The self-sufficiency ratio of south China only reduced slightly, about 0.07 percent, yet the region provides more to other regions against 1997, thus the bridge matrix still contributed positively to $\mathrm{CO}_{2}$ emissions.

Table 8. Bridge matrix changes at the regional level from 1997 to 2002 (\%).

\begin{tabular}{ccccccccc}
\hline Region & NE & NM & NC & EC & SC & CC & NW & SW \\
\hline NE & 2.60 & 2.69 & 0.87 & -0.06 & 0.26 & 0.16 & 0.98 & 0.54 \\
NM & 0.16 & -14.01 & 4.04 & -0.01 & 0.06 & 0.08 & 0.37 & 0.35 \\
NC & -1.50 & 4.06 & -9.60 & -1.14 & -0.60 & -1.06 & -0.91 & -0.71 \\
EC & -0.84 & 2.20 & 1.55 & 0.67 & 0.36 & 0.26 & 0.80 & 0.58 \\
SC & -0.41 & 5.07 & 3.14 & 0.54 & -0.07 & 0.55 & -1.25 & -0.77 \\
CC & -0.81 & 1.24 & 0.91 & 0.29 & -1.27 & -0.32 & -0.45 & -0.99 \\
NW & 0.21 & 1.23 & 0.61 & 0.21 & 0.05 & 0.11 & -4.43 & 0.45 \\
SW & 0.46 & 1.14 & 0.75 & 0.20 & 0.20 & 0.16 & 2.09 & -1.77 \\
\hline
\end{tabular}

Note: The values are based on the authors' calculations. 
Table 9. Bridge matrix changes at the regional level from 2002 to 2007 (\%).

\begin{tabular}{ccccccccc}
\hline Region & NE & NM & NC & EC & SC & CC & NW & SW \\
\hline NE & -8.29 & 0.46 & 0.51 & 0.59 & 1.13 & 1.65 & 1.21 & 0.82 \\
NM & 2.51 & 6.38 & 6.60 & 0.80 & 1.36 & 2.54 & 2.72 & 1.84 \\
NC & 0.70 & -3.05 & -6.47 & 0.48 & 1.35 & 4.29 & 2.15 & 2.01 \\
EC & 0.51 & -2.08 & -2.15 & -4.43 & 2.77 & 2.52 & 0.45 & 0.24 \\
SC & 4.58 & -1.70 & 1.50 & 2.56 & -6.61 & -11.00 & -6.53 & -4.92 \\
CC & 0.21 & -1.31 & -0.30 & 1.62 & 1.37 & -20.83 & 0.47 & 0.84 \\
NW & 0.69 & 0.59 & 2.07 & 0.95 & 1.51 & 3.78 & -14.39 & 3.23 \\
SW & 0.74 & -0.18 & -0.07 & 0.01 & 1.79 & 2.33 & 3.02 & -16.52 \\
\hline
\end{tabular}

Note: The values are based on the authors' calculations.

The same analysis of change from 2002 to 2007 is more interesting. During this period, almost all of the regions reduced their self-sufficiency ratio, yet their structure changes still contributed positively to $\mathrm{CO}_{2}$ emissions, with the exception of central China. The phenomenon definitely shows an interregional trade effect. Take northwest China as an example. From 2002 to 2007, its self-sufficiency ratio reduced by $14.4 \%$, yet it provided more of its production to all the other regions; these ratios changed in the range of $0.6 \%$ to $3.8 \%$. Note that this region had minimum levels of consumption and capital investment in both 2002 and 2007, which implies that $\mathrm{CO}_{2}$ emission reductions occurred because of decreases in its own final demand, particularly in household consumption and capital investment. However, these gains were fully offset by rises in production to meet demands from all other regions.

We can gain further insight regarding the industry structure change. From 2002 to 2007, of all the products that flowed out of northwest China to other regions, construction, trade, and transportation and electricity, gas, and water supply apparently increased their shares. These sectors are known to be more $\mathrm{CO}_{2}$-intensive than others. So, the above explains how the tilting of the structure of final demand toward household consumption and capital investment in northwest China increased that region's $\mathrm{CO}_{2}$ emissions. The analysis can also be extended into more detail, such as for different groups like urban consumption, rural consumption, government consumption, and capital investment, respectively. For space limitation reasons, we do not discuss it further here.

The effect of export structure is relatively easy to understand and it works through the interaction of export shares among regions and among sectors within the region itself. For example, when the effect contributes positively to the $\mathrm{CO}_{2}$ emission in certain region, it means either the region's export share of total export in China increased or the region is inclined to export carbon-intensive products during the study period. From 1997 to 2002, all regions increase their export share, except northeast China and southwest China. For southwest China, the intersectoral structure change within the region finally surpassed the export share change among regions, thus had a slight positive effect on $\mathrm{CO}_{2}$ emissions. Similarly, we found that during the second period, export share decreases in both south China and southwest China. Although export share in the northeast also decreased to $85 \%$ in 2007 from 2002, the products moved more to chemical, metal, and machinery sectors, which in turn leads to zero effect on $\mathrm{CO}_{2}$ emissions. The analysis is similar for the structure of inventory change.

\section{Conclusions}

The growing connections and interactions between industries and regions are becoming more and more prevalent in the economy system. Taking this into consideration, we use structural decomposition analysis to study the driving forces of China's regional carbon emission change from 1997 to 2007. Our study could incorporate energy factors, supply factors, and demand factors. Different from most studies, the further decomposition of energy factors into energy intensity and energy structure changes enabled us to see the role of energy transition in China's changing regional carbon emissions. We found that energy transition contributed only modestly to almost all regions during the study period. Still, it 
displayed great potential for improvements in the future. Our results provide a lot of information for policy formation; below we emphasize the most important items.

We found some conclusions common across China's regions. For example, the increase in consumption played an important role for increasing carbon emissions and improvement in energy intensity has been the main force in abating carbon emissions across China. Yet differences between regions existed; energy intensity contributed about 35\% to carbon abatement for north China but $82 \%$ for north municipalities in the 1997-2007 period. While other factors also affect each region's change to various degrees, even the influence on China can be absolutely ignorable. Similarly, the role of a factor can change and in different directions in different subperiods, even if it appears to have no affect over the longer period. Therefore, policies should be designed to focus on specific spatial and temporal characteristics, instead of being designed as uniform national policies. China has top-down management, so its government must be particularly careful when formulating policies for matters that display interregional disparities. In this vein, it should develop provincial targets and, perhaps, decompose even provincial targets into targets for their subjurisdictions.

Along with China's infrastructure construction and regional specialization, interregional commodity flow is becoming more frequent. Feng et al. (2013) used 2007 a 30-province I-O table and found that $57 \%$ of China's emissions are related to the goods that are produced outside the province and up to $80 \%$ of the emissions from the goods consumed in coastal areas are imported from less developed regions, such as western and central China [13]. We found interregional carbon flows had greatly increased due to higher regional trade during the study period, particularly from 2002 to 2007. For example, the carbon emissions produced by northwest China grew significantly due to intermediate input and final demand in other regions, even though its sufficiency ratio declined by more than $14 \%$. This absolutely suggests that we should expect the carbon transfer among regions within China to expand rapidly in the future, increasing differences between the production- and consumption-based accounting of carbon emissions. The government should consider this when decomposing respective provincial targets on carbon emissions and perhaps subsidize those regions with net carbon emission outflows to make all the regional responsibilities fairly consistent with the degree of the carbon emission produce versus the goods they consume. Thus, carbon emission targets in China can be fairly and efficiently reached to militate against carbon leakage within China.

Author Contributions: Conceptualization, L.Y.; Data curation, L.Y.; Formal analysis, L.Y. and M.L.L.; Investigation, L.Y. and M.L.L.; Methodology, L.Y.; Project administration, L.Y.; Software, L.Y.; Validation, L.Y.; Visualization, L.Y..; Writing-original draft, L.Y. and M.L.L.; Writing-review \& editing, M.L.L.

Funding: This research was funded by Alexander von Humboldt fellowship, the APC was funded by school of economics and finance, $\mathrm{Xi}^{\prime}$ an Jiaotong University.

Conflicts of Interest: The authors declare no conflict of interest.

\section{References}

1. Guan, D.; Weber, C.L.; Peters, G.P.; Reiner, D.M. The drivers of Chinese $\mathrm{CO}_{2}$ emissions from 1980 to 2030. Glob. Env. Chang. 2008, 18, 626-634. [CrossRef]

2. Liu, L.; Fan, Y.; Wu, G.; Wei, Y. Using LMDI method to analyze the change of China's industrial $\mathrm{CO}_{2}$ emissions from final fuel use: An empirical analysis. Energy Policy 2007, 35, 5892-5900. [CrossRef]

3. Guan, D.; Peters, G.P.; Weber, C.L.; Hubacek, K. Journey to world top emitter: An analysis of the driving forces of China's recent $\mathrm{CO}_{2}$ emissions surge. Geophys. Res. Lett. 2009, 36, L04709. [CrossRef]

4. Huang, Y.; He, J. China's regional emissions. Nat. Clim. Chang. 2011, 1, 347-349. [CrossRef]

5. Hoekstra, R.; van der Bergh, J. Comparing structural and index decomposition analysis. Energy Econ. 2003, 25, 39-64. [CrossRef]

6. Ang, B.W.; Zhang, F.Q. A survey of index decomposition analysis in energy and environmental studies. Energy 2000, 25, 1149-1176. [CrossRef]

7. Xu, X.Y.; Ang, B.W. Index decomposition analysis applied to $\mathrm{CO}_{2}$ emission studies. Ecol. Econ. 2013, 93, 313-329. [CrossRef] 
8. Su, B.; Ang, B.W. Structural decomposition analysis applied to energy and emissions: Some recent developments. Energy Econ. 2012, 34, 177-188. [CrossRef]

9. Feng, K.; Hubacek, K.; Guan, D. Lifestyles, technology and $\mathrm{CO}_{2}$ emissions in China: A regional comparative analysis. Ecol. Econ. 2009, 69, 145-154. [CrossRef]

10. Zhang, Z.; Yang, S.; Zhao, D.; Wu, Y.; Fan, J. Regional variation in carbon emissions and its driving forces in China: An index decomposition analysis. Energy Environ. 2013, 24, 1249-1270.

11. Liu, L.; Wang, J.; Wu, G.; Wei, Y. China's regional carbon emissions change over 1997-2007. Int. J. Energy Environ. 2010, 1, 161-176.

12. Liang, Q.; Fan, Y.; Wei, Y. Multi-regional input-output model for regional energy requirements and $\mathrm{CO}_{2}$ emissions in China. Energy Policy 2007, 35, 1685-1700. [CrossRef]

13. Feng, K.; Davis, S.J.; Sun, L.; Li, X.; Guan, D.; Liu, W.; Liu, Z.; Hubacek, K. Outsourcing $\mathrm{CO}_{2}$ within China. PNAS 2013, 110, 11654-11659. [CrossRef] [PubMed]

14. Meng, B.; Xue, J.; Feng, K.; Guan, D.; Fu, X. China's inter-regional spillover of carbon emissions and domestic supply chains. Energy Policy 2013, 61, 1305-1321. [CrossRef]

15. Feng, K.; Siu, Y.L.; Guan, D.; Hubacek, K. Analyzing drivers of regional carbon dioxide emissions for China. J. Ind. Ecol. 2012, 16, 600-611. [CrossRef]

16. Department of Climate Change, China's National Development and Reform Commission. The People's Republic of China Second National Communication on Climate Change; China Economic Publishing House: Beijing, China, 2013; pp. 56-68. ISBN 9787513629126.

17. China's State Information Center. Multi-Regional Input-Output Table for China, 1st ed.; Social Science Academic Press: Beijing, China, 2005; pp. 145-356. ISBN 7801905156.

18. Zhang, Y.; Qi, S. China Multi-Regional Input-Output Tables of 2002 and 2007; China Statistics Press: Beijing, China, 2012; ISBN 9787503765049.

19. Choi, K.H.; Ang, B.W. Decomposition of aggregate energy intensity changes in two measures: Ratio and difference. Energy Econ. 2003, 25, 615-624. [CrossRef]

20. Ang, B.W. Decomposition analysis for policy making in energy: Which is the preferred method? Energy Policy 2004, 32, 1131-1139. [CrossRef]

21. Su, B.; Ang, B.W. Multiplicative decomposition of aggregate carbon intensity change using input-output analysis. Appl. Energy 2015, 154, 13-20. [CrossRef]

22. Su, B.; Ang, B.W. Multiplicative structural decomposition analysis of aggregate embodied energy and emission intensities. Energy Econ. 2017, 65, 137-145. [CrossRef]

23. Liao, H.; Wang, C.; Zhu, Z.; Ma, X. Structural decomposition analysis on energy intensity changes at regional level. Trans. Tianjin Univ. 2013, 19, 287-292. [CrossRef]

24. Michel, B. Does offshoring contribute to reducing domestic air emissions? Evidence from Belgian manufacturing. Ecol. Econ. 2013, 95, 73-82. [CrossRef]

25. Zeng, L.; Xu, M.; Liang, S.; Zeng, S.; Zhang, T. Revisiting drivers of energy intensity in China during 1997-2007: A structural decomposition analysis. Energy Policy 2014, 67, 640-647. [CrossRef]

26. Wang, H.; Ang, B.W.; Su, B. Multiplicative structural decomposition analysis of energy and emission intensities: Some methodological issues. Energy 2017, 123, 47-63. [CrossRef]

27. Zhang, H.; Lahr, M.L. Households' Energy Consumption Change in China: A Multi-Regional Perspective. Sustainability 2018, 10, 2486. [CrossRef]

28. Dietzenbacher, E.; Los, B. Structural decomposition techniques: Sense and sensitivity. Econ. Syst. Res. 1998, 10, 307-323. [CrossRef]

29. De Boer, P. Generalized Fisher index or Siegel-Shapley decomposition? Energy Econ. 2009, 31, 810-814. [CrossRef]

30. De Boer, P. Multiplicative decomposition and index number theory: An empirical application of the sato-vartia decomposition number theory: An empirical application. Econ. Syst. Res. 2009, 21, 163-174. [CrossRef]

31. Dietzenbacher, E.; Los, B. Structural decomposition analyses with dependent determinants. Econ. Syst. Res. 2000, 12, 497-514. [CrossRef]

32. Dietzenbacher, E.; Lahr, M.L.; Los, B. The decline in labor compensation's share of GDP: A structural decomposition analysis for the US, 1982-1997. In Wassily Leontief and Input-Output Economics; Dietzenbacher, E., Lahr, M.L., Eds.; Cambridge University Press: Cambridge, UK, 2004; pp. 188-212. ISBN 9780521832380. 
33. Guan, D.; Liu, Z.; Geng, Y.; Lindner, S.; Hubacek, K. The gigatonne gap in China's carbon dioxide inventories. Nat. Clim. Chang. 2012, 2, 672-675. [CrossRef]

34. Liu, Z.; Guan, D.; Wei, W.; Davis, S.J.; Ciais, P.; Bai, J.; He, K. Reduced carbon emission estimates from fossil fuel combustion and cement production in China. Nature 2015, 524, 335-338. [CrossRef]

35. National Bureau of Statistics of China. 1997-1999 China Energy Statistical Yearbook; Chinese Statistics Press: Beijing, China, 2001; ISBN 9787503735578.

36. National Bureau of Statistics of China. 2000-2002 China Energy Statistical Yearbook; Chinese Statistics Press: Beijing, China, 2004; ISBN 9787503734601.

37. National Bureau of Statistics of China. 2008 China Energy Statistical Yearbook; Chinese Statistics Press: Beijing, China, 2008; ISBN 9787503756054.

38. Miller, R.E.; Blair, P.D. Input-Output Analysis: Foundations and Extensions, 2nd ed.; Cambridge University Press: Cambridge, UK, 2009; pp. 55-165. ISBN 9780521517133.

39. Yang, L.; Lahr, M.L. Sources of Chinese labor productivity growth: A structural decomposition analysis, 1987-2005. China Econ. Rev. 2010, 21, 557-570. [CrossRef]

40. Lahr, M.L. Reconciling domestication techniques, the notion of re-exports and some comments on regional accounting. Econ. Syst. Res. 2001, 13, 165-179. [CrossRef]

41. IPCC, 2006 IPCC Guidelines for National Greenhouse Gas Inventories. Available online: http://www.ipccnggip.iges.or.jp/public/2006gl/ (accessed on 9 May 2019).

42. Garbaccio, R.F.; Ho, M.S.; Jorgenson, D.W. Why has the energy-output ratio fallen in China? Energy J. 1999, 20, 63-91. [CrossRef]

43. Fisher-Vanden, K.; Jefferson, G.H.; Liu, H.; Tao, Q. What is driving China's decline in energy intensity? Resour. Energy Econ. 2004, 26, 77-97. [CrossRef]

(C) 2019 by the authors. Licensee MDPI, Basel, Switzerland. This article is an open access article distributed under the terms and conditions of the Creative Commons Attribution (CC BY) license (http://creativecommons.org/licenses/by/4.0/). 